\title{
FLAVONOL AND LIGNAN GLYCOSIDES FROM Datura metel L.
}

\author{
Nguyen Thi Mai ${ }^{1}$, Nguyen Thi Kim $\mathrm{Cuc}^{2}$, Tran Hong Quang ${ }^{2}$, Phan Van Kiem², \\ ${ }^{1}$ University of Transport and Communications, 3 Cau Giay, Dong Da, Ha Noi, Viet Nam \\ ${ }^{2}$ Institute of Marine Biochemistry, Vietnam Academy of Science and Technology (VAST), \\ 18 Hoang Quoc Viet, Cau Giay, Ha Noi, Viet Nam \\ "Email:phankiem@yahoo.com
}

Received 26 October 2015; Accepted for publication: 21 February 2017

\begin{abstract}
Chemical investigation of an acidic methanol extract of the whole plants of $D$. metel resulted in the isolation of five compounds, including kaempferol $3-O$ - $\beta$-D-glucosyl( $1 \rightarrow 2)-\beta$-Dgalactoside $7-O-\beta$-D-glucoside (1), kaempferol 3- $O$ - $\beta$-glucopyranosyl $(1 \rightarrow 2)-\beta$-glucopyranoside7- $O$ - $\alpha$-rhamnopyranoside (2), pinoresinol $O$ - $\beta$-D-glucopyranoside (3), $\left(7 R, 8 S, 7^{\prime} S, 8^{\prime} R\right)-4,9,4^{\prime}, 7^{\prime}$ tetrahydroxy-3,3'-dimethoxy-7,9'-epoxylignan-4-O- $\beta$-D-glucopyranoside (4), and $\left(7 S, 8 R, 7^{\prime} S, 8^{\prime} S\right)$ $4,9,4^{\prime}, 7^{\prime}$-tetrahydroxy-3,3'-dimethoxy-7,9'-epoxylignan-4- $O$ - $\beta$-D-glucopyranoside $\quad(\mathbf{5}) . \quad$ Their structures were elucidated by 1D and 2D NMR and MS spectroscopic analyses as well as comparing with the data reported in the literature. The absolute configurations of compounds 4 and 5 were determined by $C D$ spectra. It is noted that $\left(7 R, 8 S, 7^{\prime} S, 8^{\prime} R\right)-4,9,4^{\prime}, 7^{\prime}$-tetrahydroxy$3,3^{\prime}$-dimethoxy-7, $9^{\prime}$-epoxylignan-4- $O$ - $\beta$-D-glucopyranoside and $\left(7 S, 8 R, 7^{\prime} S, 8^{\prime} S\right)$-4, $9,4^{\prime}, 7^{\prime}$ tetrahydroxy-3,3'-dimethoxy-7,9'-epoxylignan-4- $O-\beta$-D-glucopyranoside were isolated for the first time from the Datura genus.
\end{abstract}

Keywords: Datura metel, Solanaceae, Flavonol glycoside, Lignan glycoside.

\section{INTRODUCTION}

Datura metel L. is an annual herb of the Solanaceae family and is widely cultivated in many tropical and temperate regions. In the Vietnamese traditional medicine, D. metel has been used for the treatment of coughs, bronchial asthma, and rheumatism [1]. Its leaves have been used as anesthetics in surgery, a fumigant in bronchial asthma, and anti-contractive agents in the stomach ulcers [1]. The flowers of D. metel have been used widely in the Chinese traditional medicine for the treatment of asthma, convulsions, pain, and rheumatism for centuries [2]. Previous pharmacological studies have showed that the D. metel seeds have hypoglycemic activity in normal and alloxan-induced diabetic rats [3], the chloroform extract of D. metel exhibits an antifungal effect toward several pathogenic species of Aspergillus [4], and the seeds and fruit pulps of D. metel show high antioxidant activity [5]. Previous chemical studies have demonstrated that the major chemical components of D. metel are with anolide-type steroids [6 12], which have been shown to suppress NO production in lipopolysaccharide (LPS)-stimulated RAW264.7 cells $[11,12]$ and exhibit cytotoxicity against HCT-116, A549, DLD-1, BGC-823, 
and K562 cancer cell lines [6, 7, 10]. In addition, some megastigmane sesquiterpenes and amide alkaloids from $D$. metel were also reported $[13,14]$. In the present study, we report the isolation and structural elucidation of two flavonol glycosides ( $\mathbf{1}$ and $\mathbf{2}$ ) and three lignan glycosides (3-5) from the acidic methanol extract of the whole plants of $D$. metel.

\section{MATERIAL AND METHODS}

\subsection{General experimental procedures}

All NMR spectra were recorded on a Bruker AM500 FT-NMR spectrometer (500 MHz for ${ }^{1} \mathrm{H}$ and $125 \mathrm{MHz}$ for ${ }^{13} \mathrm{C}-\mathrm{NMR}$ ), chemical shifts are reported in ppm using TMS as an internal standard. ESIMS spectra were recorded on Agilent 1100 spectrometer. Circular dichroism (CD) spectra were measured on a Chirascan CD spectrometer (Applied Photophysics Ltd., Surrey, UK). Column chromatography (CC) was performed on silica gel 230 - 400 mesh or reversed phase (RP) $\mathrm{C}_{18}$ resins (150 $\mu \mathrm{m}$, Fuji Silysia Chemical Ltd.). Compounds were visualized by spraying with aqueous $10 \% \mathrm{H}_{2} \mathrm{SO}_{4}$ and heating for 5 minutes.

\subsection{Plant material}

The whole plants of D. metel were collected in Thai Binh province, Vietnam during May 2015, and identified by Dr. Bui Van Thanh, Institute of Ecology and Biological Resources. A voucher specimen (NCCT-CDM-5.2015) was deposited at the Herbarium of the Institute of Marine Biochemistry, VAST.

\subsection{Extraction and isolation}

The dried whole plants of $D$. metel $(5 \mathrm{~kg})$ were ground and extracted with $\mathrm{MeOH} /$ acetic acid $(\mathrm{pH}=5.0)$ under sonication at room temperature. After concentration under reduced pressure, the $\mathrm{MeOH}$ extract ( $300 \mathrm{~g}$ ) was suspended in water and partitioned with $\mathrm{CHCl}_{3}$ to give $\mathrm{CHCl}_{3-}$ and water-soluble fractions. The water-soluble fraction was alkalinized by adding $\mathrm{NH}_{4} \mathrm{OH}$ until $\mathrm{pH}=9.0$, and then partitioned successively with $\mathrm{CH}_{2} \mathrm{Cl}_{2}$ and EtOAc to provide $\mathrm{CH}_{2} \mathrm{Cl}_{2^{-}}$, EtOAc-, and water-soluble fractions, respectively. The water-soluble fraction was neutralized and subjected to fractionation through a Diaion HP-20 column, eluted with a gradient of $\mathrm{MeOH}$ in water (25-100\%) to give four fractions (DMW1-DMW4). Fraction DMW2 was separated using RP $\mathrm{C}_{18}$ column chromatography (CC), eluting with $\mathrm{MeOH}-\mathrm{H}_{2} \mathrm{O}$ $(1: 3, \mathrm{v} / \mathrm{v})$ to yield subfractions DMW21-DMW25. Subfraction DMW22 was then separated by silica gel CC, eluting with $\mathrm{CH}_{2} \mathrm{Cl}_{2}-\mathrm{MeOH}-\mathrm{H}_{2} \mathrm{O}(5: 1: 0.05$, v/v/v) to give $1(25 \mathrm{mg})$ and $4(6 \mathrm{mg})$. Subfraction DMW23 was separated by silica gel CC, eluting with $\mathrm{CH}_{2} \mathrm{Cl}_{2}-\mathrm{MeOH}-\mathrm{H}_{2} \mathrm{O}$ (6:1:0.05, $\mathrm{v} / \mathrm{v} / \mathrm{v})$ and further purified by a $\mathrm{RP} \mathrm{C}_{18} \mathrm{CC}$, eluting with $\mathrm{MeOH}-\mathrm{H}_{2} \mathrm{O}(1: 3, \mathrm{v} / \mathrm{v})$ to yield $5(6 \mathrm{mg})$. Subfraction DMW25 was separated using silica gel $\mathrm{CC}$, eluting with $\mathrm{CH}_{2} \mathrm{Cl}_{2}-\mathrm{MeOH}-\mathrm{H}_{2} \mathrm{O}$ (6:1:0.05, v/v/v) and subsequently purified by $\mathrm{RP} \mathrm{C}_{18} \mathrm{CC}$, eluting with $\mathrm{MeOH}-\mathrm{H}_{2} \mathrm{O}(1: 2, \mathrm{v} / \mathrm{v})$ to release $2(20 \mathrm{mg})$. Fraction DMW42 was separated by silica gel CC, eluting with $\mathrm{CH}_{2} \mathrm{Cl}_{2^{-}}$ $\mathrm{MeOH}-\mathrm{H}_{2} \mathrm{O}(6: 1: 0.05, \mathrm{v} / \mathrm{v} / \mathrm{v})$ to provide four subfractions (DMW421-DMW424). Subfraction DMW424 was separated by $\mathrm{RP} \mathrm{C}_{18} \mathrm{CC}$, eluting with acetone- $\mathrm{H}_{2} \mathrm{O}(1: 3$, v/v) to obtain 3 (5 mg).

Kaempferol 3-O- $\beta$-D-glucosyl $(1 \rightarrow 2)-\beta-D$-galactoside 7-O- $\beta$-D-glucoside $(1)$ : yellow, amorphous powder; $\mathrm{C}_{33} \mathrm{H}_{40} \mathrm{O}_{21}, \mathrm{M}=772$; ESI-MS $m / z: 795[\mathrm{M}+\mathrm{Na}]^{+} ;{ }^{1} \mathrm{H}$ NMR (DMSO- $\left.d_{6}, 500 \mathrm{MHz}\right) \delta_{\mathrm{H}}$ : $6.43(\mathrm{~d}, J=2.0 \mathrm{~Hz}, \mathrm{H}-6), 6.80$ (d, $J=2.0 \mathrm{~Hz}, \mathrm{H}-8), 8.11$ (d, $J=8.5 \mathrm{~Hz}, \mathrm{H}-2^{\prime}$ and H-6'), 6.90 (d, $J=8.5 \mathrm{~Hz}, \mathrm{H}-3^{\prime}$ and $\left.\mathrm{H}-5^{\prime}\right), 5.68$ (d, $\left.J=7.5 \mathrm{~Hz}, \mathrm{H}-1^{\prime \prime}\right), 4.58\left(\mathrm{~d}, J=8.0 \mathrm{~Hz}, \mathrm{H}-1^{\prime \prime \prime}\right), 5.07$ (d, $J=$ $\left.7.0 \mathrm{~Hz}, \mathrm{H}-1^{\prime \prime \prime \prime}\right) ;{ }^{13} \mathrm{C}$ NMR (DMSO- $d_{6}, 125 \mathrm{MHz}$ ): see Table 1. 
Table $1 .{ }^{13} \mathrm{C}$ NMR data $(500 \mathrm{MHz})$ for compounds $\mathbf{1}-\mathbf{5}$.

\begin{tabular}{|c|c|c|c|c|c|c|c|c|c|c|}
\hline \multirow[t]{2}{*}{$\mathrm{C}$} & \multicolumn{2}{|c|}{1} & \multicolumn{2}{|l|}{2} & \multicolumn{2}{|c|}{3} & \multicolumn{2}{|c|}{4} & \multicolumn{2}{|c|}{5} \\
\hline & $\delta_{\mathrm{C}}^{\# 1}$ & $\delta_{C}{ }^{a}$ & $\delta_{C}^{\# 2}$ & $\delta_{C}^{b}$ & $\delta_{\mathrm{C}}{ }^{\# 3}$ & $\delta_{C}^{b}$ & $\delta_{\mathrm{C}}{ }^{\# 4}$ & $\delta_{C}^{a, b}$ & $\delta_{\mathrm{C}}{ }^{\# 5}$ & $\delta_{\mathrm{C}}^{\mathrm{a}, \mathrm{b}}$ \\
\hline 1 & & & & & 53.7 & 55.5 & 133.5 & 138.5 & 133.8 & 137.8 \\
\hline 2 & 156.2 & 156.2 & 159.5 & 159.4 & 85.1 & 87.5 & 110.6 & 111.7 & 110.9 & 111.8 \\
\hline 3 & 133.2 & 133.2 & 135.2 & 135.1 & & & 147.4 & 150.8 & 147.4 & 150.9 \\
\hline 4 & 177.7 & 177.7 & 180.0 & 179.7 & 71.0 & 72.6 & 145.8 & 147.1 & 145.6 & 147.6 \\
\hline 5 & 160.9 & 160.9 & 163.0 & 163.0 & 53.5 & 55.3 & 115.1 & 117.8 & 115.1 & 117.8 \\
\hline 6 & 99.4 & 99.4 & 100.7 & 100.5 & 84.9 & 87.0 & 118.9 & 120.0 & 118.9 & 120.4 \\
\hline 7 & 162.8 & 162.8 & 163.6 & 163.4 & & & 83.4 & 84.6 & 82.8 & 85.4 \\
\hline 8 & 94.5 & 94.5 & 95.6 & 95.5 & 71.0 & 72.6 & 53.9 & 53.7 & 51.9 & 55.9 \\
\hline 9 & 156.0 & 156.0 & 158.2 & 158.0 & & & 61.6 & 62.4 & 60.4 & 63.3 \\
\hline 10 & 105.6 & 105.6 & 107.6 & 107.5 & & & & & & \\
\hline $1^{\prime}$ & 120.8 & 120.8 & 122.7 & 122.5 & 132.3 & 133.7 & 138.4 & 136.0 & 138.3 & 136.2 \\
\hline $2^{\prime}$ & 131.2 & 131.2 & 132.5 & 132.4 & 110.6 & 110.9 & 111.1 & 111.5 & 110.4 & 111.4 \\
\hline $3^{\prime}$ & 115.4 & 115.4 & 116.4 & 116.3 & 146.0 & 147.0 & 148.7 & 148.9 & 148.7 & 149.0 \\
\hline $4^{\prime}$ & 160.2 & 160.2 & 161.7 & 161.8 & 147.5 & 149.1 & 145.8 & 147.3 & 145.8 & 148.5 \\
\hline $5^{\prime}$ & 115.4 & 115.4 & 116.4 & 116.3 & 115.2 & 116.0 & 114.9 & 115.9 & 114.7 & 115.9 \\
\hline $6^{\prime}$ & 131.2 & 131.2 & 132.5 & 132.4 & 118.6 & 119.7 & 119.4 & 120.7 & 118.7 & 120.8 \\
\hline $7^{\prime}$ & & & & & & & 74.8 & 76.6 & 73.7 & 77.4 \\
\hline $8^{\prime}$ & & & & & & & 50.6 & 50.8 & 49.3 & 52.7 \\
\hline $9^{\prime}$ & & & & & & & 69.5 & 71.6 & 69.5 & 71.3 \\
\hline $1^{\prime \prime}$ & 98.3 & 98.4 & 100.9 & 100.8 & 135.4 & 136.0 & 100.7 & 102.9 & 100.2 & 102.8 \\
\hline $2^{\prime \prime}$ & 80.5 & 80.5 & 82.8 & 82.6 & 110.8 & 111.5 & 73.3 & 74.9 & 73.3 & 74.9 \\
\hline $3^{\prime \prime}$ & 73.4 & 73.4 & 78.0 & 77.8 & 146.0 & 147.4 & 77.1 & 77.8 & 77.0 & 77.8 \\
\hline $4^{\prime \prime}$ & 67.7 & 67.7 & 71.3 & 71.2 & 149.1 & 150.9 & 69.7 & 71.3 & 69.7 & 71.3 \\
\hline $5^{\prime \prime}$ & 75.9 & 75.9 & 78.4 & 78.1 & 115.6 & 117.9 & 76.9 & 78.2 & 76.9 & 78.2 \\
\hline $6^{\prime \prime}$ & 60.0 & 60.0 & 62.6 & 62.4 & 118.2 & 120.0 & 60.7 & 62.5 & 60.7 & 62.5 \\
\hline $1^{\prime \prime \prime}$ & 104.3 & 104.3 & 104.8 & 104.7 & 100.4 & 102.8 & & & & \\
\hline $2^{\prime \prime \prime}$ & 74.5 & 74.4 & 75.7 & 75.5 & 73.3 & 74.8 & & & & \\
\hline $3^{\prime \prime \prime}$ & 76.5 & 76.5 & 78.0 & 77.8 & 76.8 & 77.8 & & & & \\
\hline $4^{\prime \prime \prime}$ & 69.7 & 69.7 & 71.4 & 71.2 & 70.0 & 71.3 & & & & \\
\hline $5^{\prime \prime \prime}$ & 77.0 & 77.0 & 78.3 & 78.2 & 77.0 & 78.2 & & & & \\
\hline $6^{\prime \prime \prime}$ & 60.7 & 60.7 & 62.7 & 62.5 & 60.7 & 62.4 & & & & \\
\hline $1^{\prime \prime \prime \prime \prime}$ & 99.8 & 99.8 & 99.9 & 99.7 & & & & & & \\
\hline $2^{\prime \prime \prime \prime \prime}$ & 73.1 & 73.1 & 71.8 & 71.6 & & & & & & \\
\hline $3^{\prime \prime \prime \prime \prime}$ & 76.6 & 76.6 & 72.2 & 72.0 & & & & & & \\
\hline $4^{\prime \prime \prime \prime \prime}$ & 69.7 & 69.7 & 73.7 & 73.5 & & & & & & \\
\hline $5^{\prime \prime \prime \prime}$ & 77.2 & 77.2 & 71.3 & 71.1 & & & & & & \\
\hline $6^{\prime \prime \prime \prime \prime}$ & 60.8 & 60.9 & 18.1 & 18.0 & & & & & & \\
\hline $\mathrm{OCH}_{3}$ & & & & & 55.7 & 56.3 & 55.7 & 56.7 & 55.6 & 56.7 \\
\hline & & & & & 55.9 & 56.7 & 55.8 & 56.4 & 55.7 & 56.4 \\
\hline
\end{tabular}

${ }^{a}$ Recorded in DMSO-d ${ }_{6},{ }^{b}$ in $\mathrm{CD}_{3} \mathrm{OD} ;{ }^{\# 1} \delta_{C}$ of 3-O- $\beta$-D-glucosyl $(1 \rightarrow 2)-\beta$-D-galactoside 7-O- $\beta$-D-glucoside in DMSO-d ${ }_{6}[16] ;{ }^{\# 2} \delta_{C}$ of kaempferol 3-O- $\beta$-D-glucopyranosyl $(1 \rightarrow 2)-\beta$-D-glucopyranoside-7-O- $\alpha-L$ rhamnopyranoside in $C D_{3} O D$ [17]; ${ }^{\# 3} \delta_{C}$ of pinoresinol $O-\beta$-D-glucopyranoside in DMSO-d ${ }_{6}[1] ;{ }^{\# 4} \delta_{C}$ of (7R,8S,7'S,8 R)-4,9,4',7'-tetrahydroxy-3,3'-dimethoxy-7,9'-epoxylignan-4-O- $\beta$-D-glucopyranoside in

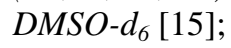

${ }^{\# 5} \delta_{C}$ of $(7 S, 8 R, 7 ' S, 8$ 'S)-4,9,4',7'-tetrahydroxy-3,3'-dimethoxy-7,9'-epoxylignan-4-O- $\beta$-D-glucopyranoside in $\mathrm{DMSO}-d_{6}[15]$. 
Kaempferol 3-O- $\beta$-D-glucopyranosyl $(1 \rightarrow 2)$ - $\beta$-D-glucopyranoside-7-O- $\alpha-L$-rhamnopyranoside (2): yellow, amorphous powder; $\mathrm{C}_{33} \mathrm{H}_{40} \mathrm{O}_{20}, \mathrm{M}=756$; ESI-MS m/z: $779[\mathrm{M}+\mathrm{Na}]^{+} ;{ }^{1} \mathrm{H} \mathrm{NMR}$ $\left(\mathrm{CD}_{3} \mathrm{OD}, 500 \mathrm{MHz}\right) \delta_{\mathrm{H}}: 6.47(\mathrm{~s}, \mathrm{H}-6), 6.76(\mathrm{~s}, \mathrm{H}-8), 8.08\left(\mathrm{~d}, J=8.5 \mathrm{~Hz}, \mathrm{H}-2^{\prime}\right.$ and H-6'), 6.93 (d, $J=8.5 \mathrm{~Hz}, \mathrm{H}-3^{\prime}$ and $\left.\mathrm{H}-5^{\prime}\right), 5.50$ (d, $\left.J=7.5 \mathrm{~Hz}, \mathrm{H}-1^{\prime \prime}\right), 4.79$ (d, $\left.J=7.5 \mathrm{~Hz}, \mathrm{H}-1^{\prime \prime \prime}\right), 5.59$ (br s, H$\left.1^{\prime \prime \prime \prime \prime}\right), 1.27$ (d, $\left.J=6.5 \mathrm{~Hz}, \mathrm{H}_{3}-6^{\prime \prime \prime \prime}\right) ;{ }^{13} \mathrm{C}$ NMR $\left(\mathrm{CD}_{3} \mathrm{OD}, 125 \mathrm{MHz}\right)$ : see Table 1.

Pinoresinol O-ק-D-glucopyranoside (3): white, amorphous powder; $\mathrm{C}_{26} \mathrm{H}_{32} \mathrm{O}_{11}, \mathrm{M}=520$; ESIMS m/z: $543[\mathrm{M}+\mathrm{Na}]^{+} ;{ }^{1} \mathrm{H}$ NMR $\left(\mathrm{CD}_{3} \mathrm{OD}, 500 \mathrm{MHz}\right) \delta_{\mathrm{H}}: 4.57(\mathrm{H}-2), 4.73(\mathrm{H}-6), 6.97\left(\mathrm{~s}, \mathrm{H}-2^{\prime}\right)$, 6.95 (d, $\left.J=8.5 \mathrm{~Hz}, \mathrm{H}-5^{\prime}\right), 6.79$ (d, $\left.J=8.5 \mathrm{~Hz}, \mathrm{H}-6^{\prime}\right), 7.05$ (s, H-2"'), 7.17 (d, $\left.J=8.5 \mathrm{~Hz}, \mathrm{H}-5^{\prime \prime}\right)$, $6.84\left(\mathrm{~d}, J=8.5 \mathrm{~Hz}, \mathrm{H}-6^{\prime \prime}\right), 4.85\left(\mathrm{~d}, J=7.5 \mathrm{~Hz}, \mathrm{H}-1^{\prime \prime \prime}\right), 3.87$ and 3.89 (each s, $\left.\mathrm{OCH}_{3}\right),{ }^{13} \mathrm{C} \mathrm{NMR}$ $\left(\mathrm{CD}_{3} \mathrm{OD}, 125 \mathrm{MHz}\right)$ : see Table 1.

(7R,8S,7'S, 8'R)-4,9,4',7'-Tetrahydroxy-3,3'-dimethoxy-7,9'-epoxylignan-4-O- $\beta$-D-

glucopyranoside (4): white, amorphous powder; $\mathrm{C}_{26} \mathrm{H}_{34} \mathrm{O}_{12}, \mathrm{M}=538$; ESI-MS $\mathrm{m} / \mathrm{z}$ : 561 $[\mathrm{M}+\mathrm{Na}]^{+} ; \mathrm{CD}(\mathrm{MeOH}) \lambda_{\max }(\Delta \mathcal{E}) 279(-7.23)$ and $231(-16.11) \mathrm{nm}[15]: \lambda_{\max }(\Delta \mathcal{E}) 277(-1.84)$ and $231(-5.34) \mathrm{nm}] ;{ }^{1} \mathrm{H}$ NMR $\left(\mathrm{CD}_{3} \mathrm{OD}, 500 \mathrm{MHz}\right) \delta_{\mathrm{H}}: 7.03(\mathrm{~d}, J=2.0 \mathrm{~Hz}, \mathrm{H}-2), 7.16(\mathrm{~d}, J=$ $8.0 \mathrm{~Hz}, \mathrm{H}-5$ ), 6.94 (dd, $J=2.0,8.0 \mathrm{~Hz}, \mathrm{H}-6), 4.70$ (d, $J=7.0 \mathrm{~Hz}, \mathrm{H}-7), 1.91$ (m, H-8), 3.33 (m, H-9a), 3.88 (m, H-9b), $6.88\left(\mathrm{~d}, J=2.0 \mathrm{~Hz}, \mathrm{H}-2^{\prime}\right), 6.76$ (d, $\left.J=8.0 \mathrm{~Hz}, \mathrm{H}-5^{\prime}\right), 6.74$ (dd, $J=2.0,8.0$ Hz, H-6'), 4.49 (d, $\left.J=8.5 \mathrm{~Hz}, \mathrm{H}-7^{\prime}\right), 2.55$ (m, H-8'), 3.98 (m, H-9'a), 4.28 (dd, $J=4.5,8.0 \mathrm{~Hz}$, H-9'b), 4.91 (d, $\left.J=7.5 \mathrm{~Hz}, \mathrm{H}-1^{\prime \prime}\right), 3.88\left(\mathrm{~s}, 3-\mathrm{OCH}_{3}\right), 3.83\left(\mathrm{~s}, 3^{\prime}-\mathrm{OCH}_{3}\right) ;{ }^{13} \mathrm{C}^{\mathrm{N} M R}\left(\mathrm{CD}_{3} \mathrm{OD}, 125\right.$ MHz): see Table 1.

(7S,8R,7'S, 8'S)-4,9,4',7'-Tetrahydroxy-3,3'-dimethoxy-7,9'-epoxylignan-4-O- $\beta$-D-

glucopyranoside (5): white, amorphous powder; $\mathrm{C}_{26} \mathrm{H}_{34} \mathrm{O}_{12}, \mathrm{M}=538$; ESI-MS $\mathrm{m} / \mathrm{z}: 561$ $[\mathrm{M}+\mathrm{Na}]^{+} ; \mathrm{CD}(\mathrm{MeOH}) \lambda_{\max }(\Delta \varepsilon) 284(+0.52), 233(+17.45) \mathrm{nm}[15]: \lambda_{\max }(\Delta \mathcal{E}) 281(+0.88)$ and $234(+1.19) \mathrm{nm}] ;{ }^{1} \mathrm{H}$ NMR $\left(\mathrm{CD}_{3} \mathrm{OD}, 500 \mathrm{MHz}\right) \delta_{\mathrm{H}}: 7.03$ (br s, H-2), 7.16 (d, $\left.J=8.5 \mathrm{~Hz}, \mathrm{H}-5\right)$, 6.93 (br d, $J=8.5 \mathrm{~Hz}, \mathrm{H}-6$ ), 4.60 (d, $J=8.5 \mathrm{~Hz}, \mathrm{H}-7$ ), 2.29 (m, H-8), 3.67 (m, $\mathrm{H}_{2}-9$ ), 7.01 (br s, H-2'), 6.80 (d, $\left.J=8.0 \mathrm{~Hz}, \mathrm{H}-5^{\prime}\right), 6.85$ (dd, $\left.J=1.5,8.0 \mathrm{~Hz}, \mathrm{H}-6^{\prime}\right), 4.50$ (d, $\left.J=9.0 \mathrm{~Hz}, \mathrm{H}-7^{\prime}\right), 2.64$ (m, H-8'), 3.67 (m, H-9'a), 3.77 (dd, $J=6.5,9.0 \mathrm{~Hz}, \mathrm{H}-9^{\prime} \mathrm{b}$ ), 4.86 (d, $\left.J=7.5 \mathrm{~Hz}, \mathrm{H}-1^{\prime \prime}\right), 3.89$ (s, $3-\mathrm{OCH}_{3}$ and $\left.3^{\prime}-\mathrm{OCH}_{3}\right) ;{ }^{13} \mathrm{C}$ NMR $\left(\mathrm{CD}_{3} \mathrm{OD}, 125 \mathrm{MHz}\right)$ : see Table 1.

\section{RESULTS AND DISCUSSION}

Compound 1 was obtained as a yellow, amorphous powder. Its molecular formula was established as $\mathrm{C}_{33} \mathrm{H}_{40} \mathrm{O}_{21}$ by an ion peak $[\mathrm{M}+\mathrm{Na}]^{+}$at $\mathrm{m} / \mathrm{z} 795$ in the ESIMS and the ${ }^{13} \mathrm{C}$ NMR spectroscopic analysis. The ${ }^{1} \mathrm{H}$ NMR of 1 showed signals for two meta coupled aromatic protons at $\delta_{\mathrm{H}} 6.43(\mathrm{~d}, J=2.0 \mathrm{~Hz}, \mathrm{H}-6)$ and $6.80(\mathrm{~d}, J=2.0 \mathrm{~Hz}, \mathrm{H}-8)$ and a para-substituted aromatic ring at $\delta_{\mathrm{H}} 8.11\left(\mathrm{~d}, J=8.5 \mathrm{~Hz}, \mathrm{H}-2^{\prime}\right.$ and $\left.\mathrm{H}-6^{\prime}\right)$ and $6.90\left(\mathrm{~d}, J=8.5 \mathrm{~Hz}, \mathrm{H}-3^{\prime}\right.$ and $\left.\mathrm{H}-5^{\prime}\right)$. The ${ }^{1} \mathrm{H} \mathrm{NMR}$ spectrum further showed signals for three anomeric protons at $\delta_{\mathrm{H}} 5.68\left(\mathrm{~d}, J=7.5 \mathrm{~Hz}, \mathrm{H}-1^{\prime \prime}\right)$, 4.58 (d, $\left.J=8.0 \mathrm{~Hz}, \mathrm{H}-1^{\prime \prime \prime}\right)$, and 5.07 (d, $\left.J=7.0 \mathrm{~Hz}, \mathrm{H}-1^{\prime \prime \prime \prime}\right)$, revealing that 1 has three sugar units. Analysis of ${ }^{13} \mathrm{C}$ NMR and HSQC spectra indicated the presence of 33 carbons, including one carbonyl carbon at $\delta_{\mathrm{C}} 177.7$ (C-4), eight non-protonated aromatic carbons (of which five were oxygenated), and six aromatic methine carbons, suggesting that 1 possesses the flavonol skeleton (Table 1). The 18 remaining carbons were assigned to three sugar units, which were identified as two glucopyranoses and one galactopyranose by comparison with those reported in the literature [16]. The relatively large spin couplings of the three anomeric protons $(J \geq 7.0 \mathrm{~Hz})$ are characteristic features of the $\beta$-configurations for the glucose and galactose units. In the HMBC spectrum, the HMBC correlations from $\delta_{\mathrm{H}} 4.58\left(\mathrm{H}-1^{\prime \prime \prime}\right)$ to $\delta_{\mathrm{C}} 80.5\left(\mathrm{C}-2^{\prime \prime}\right)$ and from $\delta_{\mathrm{H}}$ 
5.68 (H-1") to $\delta_{\mathrm{C}} 98.4(\mathrm{C}-3)$ suggested that the $\beta$-glucopyranosyl-( $\left.\left.1 \rightarrow 2\right)\right]$ - $\beta$-D-galactopyranoside sugar chain was located at $\mathrm{C}-3$ position (Figure 2 ). The remaining $\beta$-glucopyranose was attached to $\mathrm{C}-7$ by the HMBC correlation observed from $\delta_{\mathrm{H}} 5.07$ (H-1"'"') to $\delta_{\mathrm{C}} 162.8(\mathrm{C}-7)$. On the basis of the above analysis, along with comparison with those of the reported flavonol glycoside [16], the structure of 1 was established as kaempferol 3- $O$ - $\beta$-D-glucosyl $(1 \rightarrow 2)-\beta$-D-galactoside $7-O-\beta$ D-glucoside.
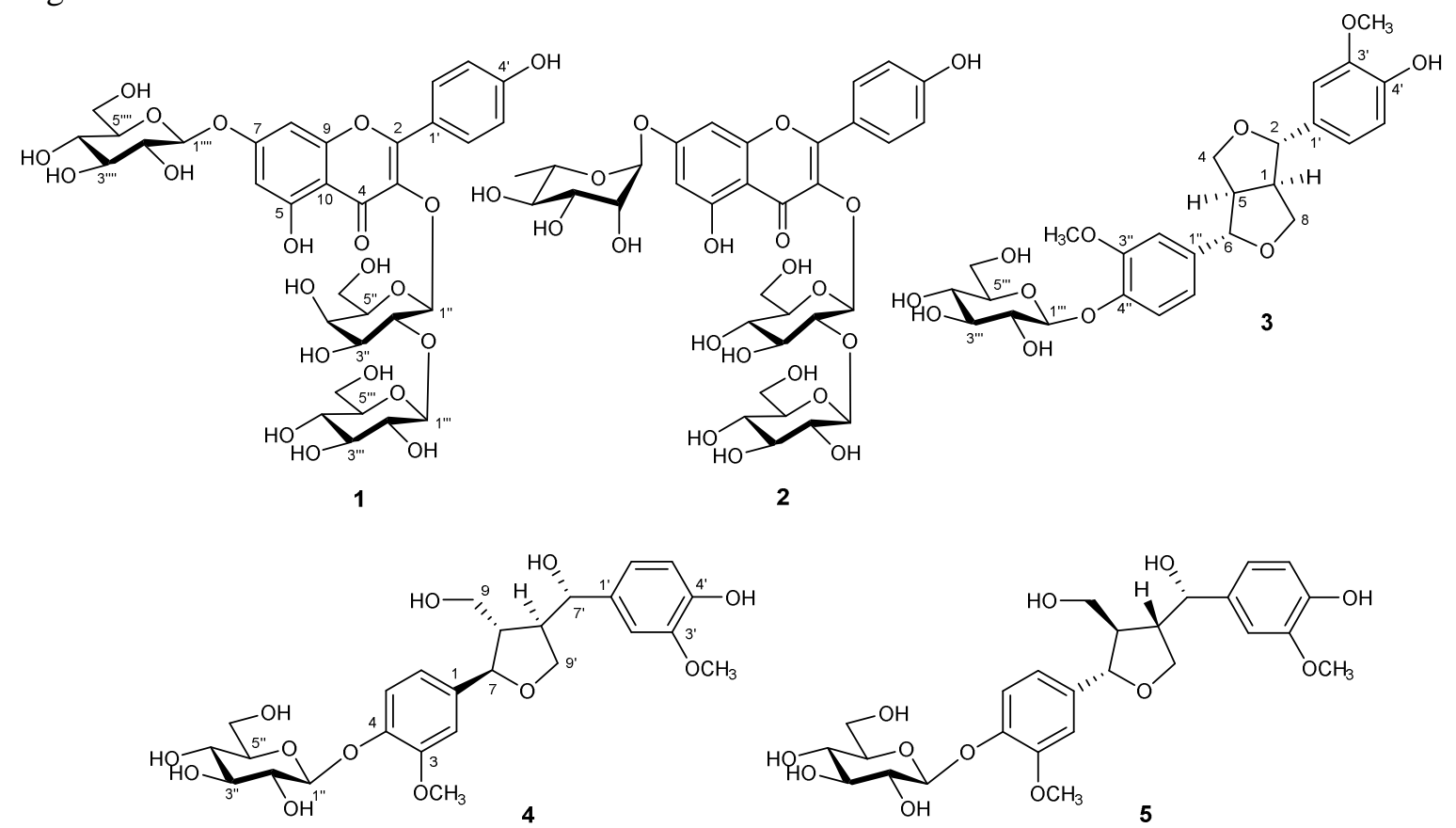

Figure 1. Chemical structures of compounds 1-5 from D. metel.

The molecular formula of compound 2 was determined to be $\mathrm{C}_{33} \mathrm{H}_{40} \mathrm{O}_{20}$ by the presence of an ion $[\mathrm{M}+\mathrm{Na}]^{+}$at $m / z, 779$ in the ESIMS. The ${ }^{1} \mathrm{H}$ NMR spectrum contained signals for an AX spin system $\left[\delta_{\mathrm{H}} 6.47(\mathrm{~s}, \mathrm{H}-6)\right.$ and $\left.6.76(\mathrm{~s}, \mathrm{H}-8)\right]$ and an $\mathrm{AA}^{\prime} \mathrm{BB}^{\prime}$ pattern at $\delta_{\mathrm{H}} 8.08(\mathrm{~d}, J=8.5 \mathrm{~Hz}$, H-2' and H-6 $\left.{ }^{\prime}\right)$ and 6.93 (d, $J=8.5 \mathrm{~Hz}, \mathrm{H}-3^{\prime}$ and H-5'). The signals for three anomeric protons at $\delta_{\mathrm{H}} 5.50\left(\mathrm{~d}, J=7.5 \mathrm{~Hz}, \mathrm{H}-1^{\prime \prime}\right), 4.79$ (d, $\left.J=7.5 \mathrm{~Hz}, \mathrm{H}-1^{\prime \prime \prime}\right)$, and 5.59 (br s, H-1'"'”) observed in the ${ }^{1} \mathrm{H}$ NMR spectrum indicated the presence of three sugars in the structure. The ${ }^{13} \mathrm{C}$ NMR spectrum comprised 33 carbon signals, including 15 carbons of the aglycone and 18 carbons belonging to the sugar moiety (Table 1). Comparison of the ${ }^{1} \mathrm{H}$ and ${ }^{13} \mathrm{C}$ NMR data of 2 with those of 1 revealed that these compounds have the same aglycone but different sugar moieties. The sugar moiety of $\mathbf{2}$ was found to consist of two glucose units and one rhamnose by detailed analysis of ${ }^{13} \mathrm{C}$ NMR and HSQC spectra in comparison with the previously reported values [17]. The $\beta$-configurations for the anomeric protons of the glucopyranoses were deduced based on the relatively large coupling constants $(J=7.5 \mathrm{~Hz})$, while the $\alpha$-oriented anomeric proton of the rhamose was determined by its carbon chemical shift values of C-3 and C-5 positions [19]. The sugar chain at $\mathrm{C}-3$ of the aglycone was identified as $\beta$-D-glucopyranosyl( $1 \rightarrow 2)-\beta$-Dglucopyranoside by the HMBC correlations from $\delta_{\mathrm{H}} 4.79\left(\mathrm{H}-1^{\prime \prime \prime}\right)$ to $\delta_{\mathrm{C}} 82.6\left(\mathrm{C}-1^{\prime \prime}\right)$ and from $\delta_{\mathrm{H}}$ $5.50\left(\mathrm{H}-1^{\prime \prime}\right)$ to $\delta_{\mathrm{C}} 135.1(\mathrm{C}-3)$ (Figure 2). The location of the rhamnose at C-7 position was deduced by the HMBC cross-peak between $\delta_{\mathrm{H}} 5.59$ (H-1"'") to $\delta_{\mathrm{C}} 163.4(\mathrm{C}-7)$. Thus, the 
structure of $\mathbf{2}$ was identified as kaempferol 3-O- $\beta$-D-glucopyranosyl( $1 \rightarrow 2)-\beta-$ Dglucopyranoside-7- $O$ - $\alpha$-L-rhamnopyranoside.

Compound 3 was isolated as a white, amorphous powder. Its molecular formula, $\mathrm{C}_{26} \mathrm{H}_{32} \mathrm{O}_{11}$ was deduced by the observation of an ion peak $[\mathrm{M}+\mathrm{Na}]^{+}$at $\mathrm{m} / z 543$ in the ESIMS and ${ }^{13} \mathrm{C}$ NMR spectroscopic analysis. The ${ }^{1} \mathrm{H}$ NMR spectrum exhibited signals for two ABX spin systems at $\delta_{\mathrm{H}}$ 6.97 (s, H-2'), 6.95 (d, $\left.J=8.5 \mathrm{~Hz}, \mathrm{H}-5^{\prime}\right), 6.95$ (d, $\left.J=8.5 \mathrm{~Hz}, \mathrm{H}-6^{\prime}\right), 7.05$ (s, H-2'), 7.17 (d, $J=$ $\left.8.5 \mathrm{~Hz}, \mathrm{H}-5^{\prime \prime}\right)$, and $6.84\left(\mathrm{~d}, J=8.5 \mathrm{~Hz}, \mathrm{H}-6^{\prime \prime}\right)$ and two methoxy groups at $\delta_{\mathrm{H}} 3.87$ and 3.89 (each $\mathrm{s}, 4^{\prime}-\mathrm{OCH}_{3}$ and $\left.4^{\prime \prime}-\mathrm{OCH}_{3}\right)$. The signal of an anomeric proton at $\delta_{\mathrm{H}} 4.85\left(\mathrm{~d}, J=7.5 \mathrm{~Hz}, \mathrm{H}-1^{\prime \prime \prime}\right)$ observed in the ${ }^{1} \mathrm{H}$ NMR of 3 implied the presence of a sugar unit. The ${ }^{13} \mathrm{C}$ NMR and DEPT spectra displayed 26 carbon signals, of which six nonprotonated aromatic carbons (including four were oxygenated), six aromatic methines, two oxymethines at $\delta_{\mathrm{C}} 87.5(\mathrm{C}-2)$ and $87.0(\mathrm{C}-6)$, two oxymethylenes at $\delta_{\mathrm{C}} 72.6\left(\mathrm{C}-4\right.$ and C-8), two methines at $\delta_{\mathrm{C}} 55.5(\mathrm{C}-1)$ and $55.3(\mathrm{C}-5)$, suggesting that 3 is a lignan derivative (Table 1). The six remaining carbon signals at $\delta_{\mathrm{C}} 102.8$, $74.8,77.8,71.3,78.2$, and 62.4 could be assigned to a glucopyranose. Comparison of the ${ }^{1} \mathrm{H}$ and ${ }^{13} \mathrm{C}$ NMR data of 3 with those of the reported lignan, pinoresinol $O-\beta$-D-glucopyranoside, revealed that the structures of these compounds are identical [18]. Therefore, the structure of compound $\mathbf{3}$ was identified as shown in Figure 1.

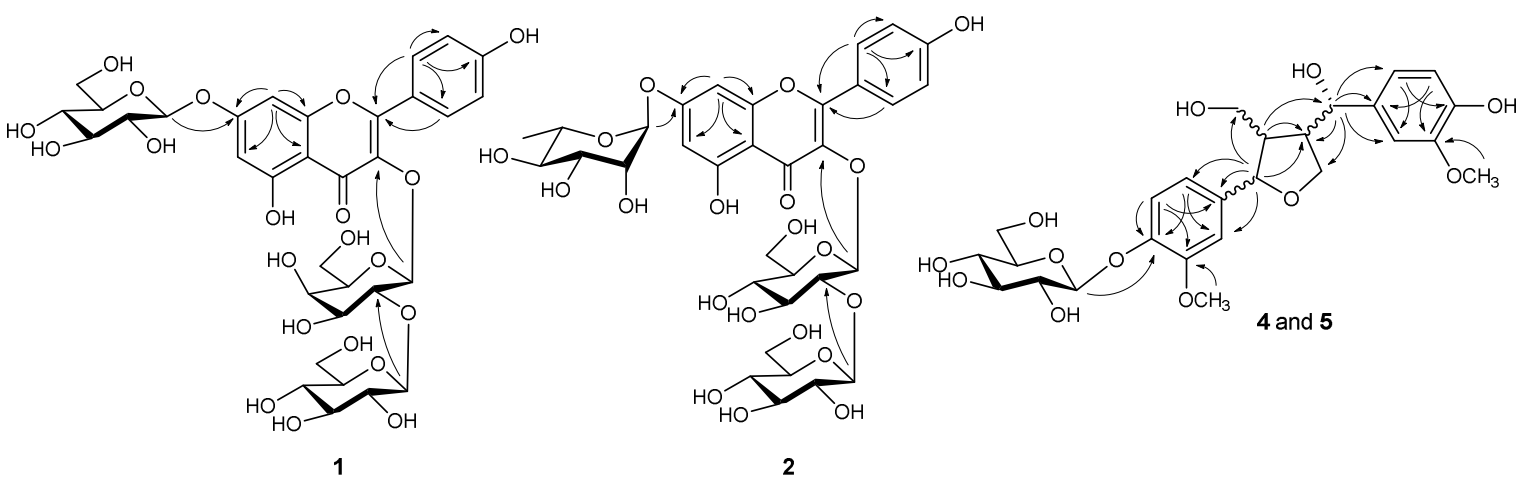

Figure 2. Selected HMBC correlations of compounds 1, 2, 4, and $\mathbf{5 .}$

The ESIMS of compound 4 exhibited an ion $[\mathrm{M}+\mathrm{Na}]^{+}$at $\mathrm{m} / \mathrm{z} 561$, corresponding with the molecular formula $\mathrm{C}_{26} \mathrm{H}_{34} \mathrm{O}_{12}$. The ${ }^{1} \mathrm{H}$ NMR spectrum showed signals for two ABX spin systems at $\delta_{\mathrm{H}} 7.03(\mathrm{~d}, J=2.0 \mathrm{~Hz}, \mathrm{H}-2), 7.16(\mathrm{~d}, J=8.0 \mathrm{~Hz}, \mathrm{H}-5), 6.94(\mathrm{dd}, J=1.5,8.5 \mathrm{~Hz}, \mathrm{H}-6), 6.88(\mathrm{~d}$, $\left.J=2.0 \mathrm{~Hz}, \mathrm{H}-2^{\prime}\right), 6.76\left(\mathrm{~d}, J=8.0 \mathrm{~Hz}, \mathrm{H}-5^{\prime}\right)$, and $6.74\left(\mathrm{dd}, J=2.0,8.0 \mathrm{~Hz}, \mathrm{H}-6^{\prime}\right)$ and two methoxy groups at $\delta_{\mathrm{H}} 3.88\left(\mathrm{~s}, 3-\mathrm{OCH}_{3}\right)$ and $3.83\left(3^{\prime}-\mathrm{OCH}_{3}\right)$. Compound 4 was found to have one sugar unit by the observation of an anomeric proton at $\delta_{\mathrm{H}} 4.91\left(\mathrm{~d}, J=7.5 \mathrm{~Hz}, \mathrm{H}-1^{\prime \prime}\right)$ in the ${ }^{1} \mathrm{H}$ NMR spectrum. Analysis of ${ }^{13} \mathrm{C}$ NMR and HSQC spectra indicated the presence of 26 carbons, including six non-protonated aromatic carbons (of which four were oxygenated), six aromatic methines, two oxymethines at $\delta_{\mathrm{H}} 4.70 / \delta_{\mathrm{C}} 84.6(\mathrm{C}-7)$ and $\delta_{\mathrm{H}} 4.49 / \delta_{\mathrm{C}} 76.6\left(\mathrm{C}-7^{\prime}\right)$, two oxymethylenes at $\delta_{\mathrm{H}} 3.33$ and $3.88 / \delta_{\mathrm{C}} 62.4(\mathrm{C}-9)$ and $\delta_{\mathrm{H}} 3.98$ and $4.28 / \delta_{\mathrm{C}} 71.6\left(\mathrm{C}-9^{\prime}\right)$, suggesting that 4 belongs to the lignan skeleton (Table 1 ). The sugar was suggested to be $\beta$-glucopyranose by the observation of six carbon signals at $\delta_{\mathrm{C}} 102.9,74.9,77.8,71.3,78.2$, and 62.5 and the large coupling constant of the anomeric proton $(J=7.5 \mathrm{~Hz})$. Comparison of the ${ }^{1} \mathrm{H}$ and ${ }^{13} \mathrm{C}$ NMR data of 4 with those of the reported lignan glycoside, tetrahydroxy-3,3'-dimethoxy-7,9'epoxylignan-4-O- $\beta$-D-glucopyranoside resulted in the close similarity [15]. In the HMBC 
spectrum, the HMBC correlations from $\delta_{\mathrm{H}} 4.70(\mathrm{H}-7)$ to $\delta_{\mathrm{C}} 138.5(\mathrm{C}-1), 111.7(\mathrm{C}-2)$, and 120.0

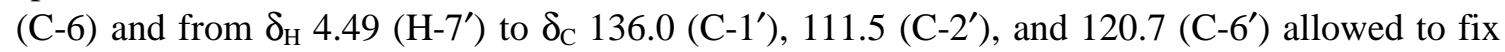
the location of the two 1,3,4-trisubstituted aromatic rings at $\mathrm{C}-7$ and $\mathrm{C}-7^{\prime}$, respectively (Figure 2). The HMBC correlations from $\delta_{\mathrm{H}} 3.88$ to $\delta_{\mathrm{C}} 150.8(\mathrm{C}-3)$ and from $\delta_{\mathrm{H}} 3.83$ to $\delta_{\mathrm{C}} 148.9\left(\mathrm{C}-3^{\prime}\right)$ indicated that the two methoxyl groups are located at $\mathrm{C}-3$ and $\mathrm{C}-3^{\prime}$ positions. The position of the $\beta$-glucopyranose was determined to be at C-4 based on the HMBC correlations observed from $\delta_{\mathrm{H}} 6.94(\mathrm{H}-2)$ to $\delta_{\mathrm{C}} 147.1(\mathrm{C}-4)$ and from $\delta_{\mathrm{H}} 4.91\left(\mathrm{H}-1^{\prime \prime}\right)$ to $\delta_{\mathrm{C}} 147.1(\mathrm{C}-4)$. Based on the above analysis, the planar structure of $\mathbf{4}$ was established. The $\mathrm{CD}$ spectrum of $\mathbf{4}$ showed the negative Cotton effects at $279 \mathrm{~nm}(\Delta \varepsilon-7.23)$ and $231 \mathrm{~nm}(\Delta \varepsilon-16.11)$, which were in good agreement with those of the related compound, indicating the absolute configuration of $\mathbf{4}$ to be $7 R, 8 S, 7^{\prime} S, 8^{\prime} R$ [15]. Thus, the structure of $\mathbf{4}$ was established as $\left(7 R, 8 S, 7^{\prime} S, 8^{\prime} R\right)-4,9,4^{\prime}, 7^{\prime}$-tetrahydroxy-3,3'dimethoxy-7,9'-epoxylignan-4- $O$ - $\beta$-D-glucopyranoside.

The molecular formula of compound $\mathbf{5}, \mathrm{C}_{26} \mathrm{H}_{34} \mathrm{O}_{12}$ was deduced by its ESIMS ion at $\mathrm{m} / \mathrm{z}$ $561[\mathrm{M}+\mathrm{Na}]^{+}$and ${ }^{1} \mathrm{H}$ and ${ }^{13} \mathrm{C}$ NMR spectra. The ${ }^{1} \mathrm{H}$ and ${ }^{13} \mathrm{C}$ NMR data of 5 were found to be very similar with those of 4 , except for the carbon chemical shift values of C-8 (5: $\delta_{\mathrm{C}} 55.9$ vs 4 : $\left.\delta_{\mathrm{C}} 53.7\right)$ and C-8' $\left(5: \delta_{\mathrm{C}} 52.7\right.$ vs $\left.4: \delta_{\mathrm{C}} 50.8\right)$, suggesting that these compounds are stereoisomers at C-8 and C-8' (Table 1). This was supported by comparing the CD spectrum of $\mathbf{5}$ with that of the reported lignan glycoside, $\left(7 S, 8 R, 7^{\prime} S, 8^{\prime} S\right)-4,9,4^{\prime}, 7^{\prime}$-tetrahydroxy-3,3'-dimethoxy-7,9'epoxylignan-4-O- $\beta$-D-glucopyranoside [5: $\lambda_{\max }(\Delta \mathcal{E}) 284(+0.52)$ and $233(+17.45) \mathrm{nm}$ vs. $\lambda_{\max }$ $(\Delta \varepsilon) 281(+0.88)$ and $234(+1.19) \mathrm{nm}[15]$. Hence, the structure of 5 was identified as shown in Figure 1.

\section{CONCLUSION}

Our chemical study of the acidic methanol extract of the $D$. metel whole plants led to the isolation and identification of five compounds, namely: kaempferol 3-O- $\beta$-D-glucosyl $(1 \rightarrow 2)-\beta$ D-galactoside $\quad 7-O$ - $\beta$-D-glucoside (1), kaempferol $\quad 3-O$ - $\beta$-D-glucopyranosyl $(1 \rightarrow 2)-\beta$-Dglucopyranoside-7- $O-\alpha$-L-rhamnopyranoside (2), pinoresinol $O$ - $\beta$-D-glucopyranoside (3), ( $\left.7 R, 8 S, 7^{\prime} S, 8^{\prime} R\right)-4,9,4^{\prime}, 7^{\prime}$-tetrahydroxy-3,3'-dimethoxy-7,9'-epoxylignan-4- $O$ - $\beta$-D-glucopyranoside (4), and $\left(7 S, 8 R, 7^{\prime} S, 8^{\prime} S\right)-4,9,4^{\prime}, 7^{\prime}$-tetrahydroxy-3, $3^{\prime}$-dimethoxy-7, $9^{\prime}$-epoxylignan-4- $O$ - $\beta$-Dglucopyranoside (5). Among the isolates, $\left(7 R, 8 S, 7^{\prime} S, 8^{\prime} R\right)-4,9,4^{\prime}, 7^{\prime}$-tetrahydroxy-3, $3^{\prime}$-dimethoxy7,9'-epoxylignan-4- $O$ - $\beta$-D-glucopyranoside and $\left(7 S, 8 R, 7^{\prime} S, 8^{\prime} S\right)-4,9,4^{\prime}, 7^{\prime}$-tetrahydroxy-3,3'dimethoxy-7,9'-epoxylignan-4- $O$ - $\beta$-D-glucopyranoside were reported for the first time from the Datura genus.

Acknowledgement. This research was supported by NAFOSTED under grant number 104.01-2014.69.

\section{REFERENCES}

1. Chi V. V. - Dictionary of medicinal plants in Vietnam, Vietnamese Publisher of Medicine, Vol. 1, 2012, pp. 284.

2. Xiao P. G. - Modern Chinese Materia Medica. Chemical Industry Publishing House, Beijing, 2002, pp. 757.

3. Krishna Murthy B., Nammi S., Kota M. K., Krishna Rao R. V., Koteswara Rao N., Annapurna A. - Evaluation of hypoglycemic and antihyperglycemic effects of Datura 
metel (Linn.) seeds in normal and alloxan-induced diabetic rats, J. Ethnopharmacol. 91 (2004) 95-98.

4. Rajesh Sharma G. L. - Studies on antimycotic properties of Datura metel, J. Ethnopharmacol. 80 (2002) 193-197.

5. Roy S., Pawar S., Chowdhary A. - Evaluation of In Vitro Cytotoxic and Antioxidant Activity of Datura metel Linn. and Cynodon dactylon Linn, Extracts. Pharmacognosy Res. 8 (2016) 123-127.

6. Ma L., Xie C. M., Li J., Lou F. C., Hu L. H. - Daturametelins H, I, and J: three new withanolide glycosides from Datura metel L. Chem. Biodivers. 3 (2006) 180-186.

7. Pan Y., Wang X., Hu X. - Cytotoxic withanolides from the flowers of Datura metel, J. Nat. Prod. 70 (2007) 1127-1132.

8. Yang B. Y., Xia Y. G., Wang Q. H., Dou D. Q., Kuang H. X. - Baimantuoluosides D-G, four new withanolide glucosides from the flower of Datura metel L, Arch. Pharm. Res. 33 (2010) 1143-1148.

9. Kuang H. X., Yang B. Y., Xia Y. G., Wang Q. H. - Two new withanolide lactones from flos daturae, Molecules 16 (2011) 5833-5839.

10. Bellila A., Tremblay C., Pichette A., Marzouk B., Mshvildadze V., Lavoie S., Legault J. Cytotoxic activity of withanolides isolated from Tunisian Datura metel L, Phytochemistry 72 (2011) 2031-2036.

11. Yang B. Y., Guo R., Li T., Liu Y., Wang C. F., Shu Z. P., Wang Z. B., Zhang J., Xia Y. G., Jiang H., Wang Q. H., Kuang H. X. - Five withanolides from the leaves of Datura metel L. and their inhibitory effects on nitric oxide production, Molecules 19 (2014) 45484559.

12. Yang B. Y., Guo R., Li T., Wu J. J., Zhang J., Liu Y., Wang Q. H., Kuang H. X. - New antiinflammatory withanolides from the leaves of Datura metel L, Steroids 87 (2014) 26-34.

13. Kuang H. X., Yang B. Y., Xia Y. G., Feng W. S. - Chemical constituents from the flower of Datura metel L, Arch. Pharm. Res. 31 (2008) 1094-1097.

14. Yang B. Y., Xia Y. G., Wang Q. H., Dou D. Q., Kuang H. X. - Two new amide alkaloids from the flower of Datura metel L, Fitoterapia 81 (2010) 1003-1005.

15. Yang Y. N., Huang X. Y., Feng Z. M., Jiang J. S., Zhang P. C. - Hepatoprotective activity of twelve novel 7'-hydroxy lignan glucosides from Arctii Fructus, J. Agric. Food Chem. 62 (2014) 9095-9102.

16. Han Y., Nishibe S., Noguchi Y., Jin Z. - Flavonol glycosides from the stems of Trigonella foenum-graecum, Phytochemistry 58 (2001) 577-580.

17. Kite G. C., Veitch N. C., Boalch M. E., Lewis G. P., Leon C. J., Simmonds M. S. Flavonol tetraglycosides from fruits of Styphnolobium japonicum (Leguminosae) and the authentication of Fructus Sophorae and Flos Sophorae, Phytochemistry, 70 (2009) 785-794.

18. Deyama T. - The Constituents of Eucommia ulmoides OLIV. I. Isolation of (+)Medioresinol Di-O-b-D-glucopyranoside, Chem. Pharm. Bull. 31 (1983) 2993-2997.

19. Kasai R., Okihara M., Asakawa J., Mizutani K., Tanaka O. $-{ }^{13} \mathrm{C}$ nmr study of alpha- and beta-anomeric pairs of d-mannopyranosides and 1-rhamnopyranosides, Tetrahedron 35 (1979) 1427-1432. 